\title{
ECONOMIC TRANSITION AS CONTINUITY (ON THE TRANSITION FROM FEUDALISM TO CAPITALISM IN SLOVENIA)
}

\begin{abstract}
The aim of this paper is to establish the common features of the transition process from feudalism to the capitalist economic system in Slovenia. In the processes of the transition to the capitalist economy, Slovenia was on the European periphery. The export demand was the driving force of structural changes in the regional economy, as the weak internal demand was not in the position to foster economic development. Slovenian economy and society entered these processes with a delay of decades as well as with some discontinuity in the form of re-agrarization and de-industrialization, as it is outlined in the concept of proto-industrialization. During the periods of re-agrarization the model of distribution of the existing resources was predominant. It manifested itself in the form of the fragmentation of agricultural ownership structure, which was the most significant factor of the relative economic backwardness of the Slovenian territory. The Slovenian economic subjects were small, under-capitalized, and with outdated technology, and therefore uncompetitive on the interregional markets. So the prime instigators of the economic changes were foreign entrepreneurs with their know-how, capital, technology, and international markets. In the period before World War II the role of foreign investments was crucial for the process of the transformation into the capitalist economy. The most significant historical feature of the Slovenian economic development is the fact that the existing »islands of modernization", which were more or less in line with European trends, remained »islands« until their power to stimulate structural changes and new institutional forms in economy vanished completely in the predominantly agrarian economic and social environment.
\end{abstract}

Key words: economic transtition, economic development, social transformation, Slovenia

Professor Žarko Lazarević, PhD, Institute for Contemporary History, Ljubljana, Slovenia, e-mail: zarko.lazarevic@inz.si 
In the modern discourse the concept of economic transition relates to the economic and social transformation of the former communist countries in the 1990s. Transition has been defined as a concept, denoting the economy undergoing a process of transformation from the centrally-planned structure to the market economy. ${ }^{1}$ In its essence transition denotes an all-encompassing transformation of the economic system. It presupposes a complete takeover of the formal and informal market institutions and the abolishment of the communist economic system. In view of the substantive level of changes the term »transformation " would be more suitable, which is also proposed and used by some authors in the social sciences. ${ }^{2}$ If we disregard the exceedingly modern connotation of the concept of transition and apply it in the sense of the transformation from one economic system to another, different economic system, then other possibilities open up for us as well. Namely, the concept of economic transition in the sense of the transition to another economic system may also be used in order to denote the processes that dissolved the feudal economic structure and led to the transition to the capitalist economic system. These were two transitions during which the social and economic institutions had to be transformed. ${ }^{3}$ In the case of the transition in the 1990s this involved a centralised and super-

For the methodological definition of the concept of transition and its first interpretative use in the Slovenian historiography see Lorenčič, Aleksander (2012), Prelom s starim in začetek novega. Tranzicija slovenskega gospodarstva iz socializma v kapitalizem. (19902004) [A Break with the Old and the Beginning of Something New: Slovenian Economic Transition from Socialism to Capitalism (1990-2004)]. Ljubljana: INZ.

2 For terminological and substantive dimensions of these differences see scientific review articles Rakita, Milan (2011): Prilog kritici teorija modernizacije i tranzitologije u društvenim naukama [Contribution to the Criticism of the Theories of Modernisation and Transitology in Social Sciences]. In: Veselinović, Ana, Atanacković, Petar, Klarić, Željko, Izgubljeno u tranziciji. Kritička analiza procesa društvene transformacije [Lost in Transition. Critical Analysis of the Social Transformation Process]. Belgrade: Rosa Luxemburg Stiftung, pp. 7-32 and Tomić, Đorđe (2011): Od transformacije do tranzicije i nazad. Nauka o transformaciji? Pojmovi, pitanja, teorije [From Transformation to Transition and Back. Science of Transformation? Concepts, Questions, Theories]. In: Veselinović, Ana, Atanacković, Petar, Klarić, Željko, Izgubljeno u tranziciji. Kritička analiza procesa društvene transformacije [Lost in Transition. Critical Analysis of the Social Transformation Process]. Belgrade: Rosa Luxemburg Stiftung, pp. 33-56.

3 Social institutions are defined as the manifestations of formal and informal nature, regardless of the level of institutionalisation, in the field of mental structures, schemes, rules, norms and traditions, defining, as social standards, the behaviour in the society and economy in an authoritarian manner. A clear identification of these institutions and their forms in view of the temporal dynamics enables us to gain insight into the process characteristics of the development of individual societies, while the comparative aspect allows for the consideration of the relevance of their general validity. For more information about the institutional theory see NORTH, Douglas C. (1998): Inštitucije, inštitucionalne spremembe in gospodarska uspešnost [Institutions, Institutional Change and Economic Performance]. Ljubljana: Krtina; NORTH, Douglas C. (2005): Understanding the Process of Economic Change. Princeton: Princeton University Press. 
vised process of the formation of new institutions, which was supposed to take approximately two decades. On the other hand the transition from feudalism to capitalism was decentralised, slow and gradual. Unlike the modern understanding of economic transition, where the processes can be measured in mere decades, the latter involved processes which took centuries.

The purpose of this discussion is to find the common elements of the transition from feudalism to capitalism in the last few centuries. For this purpose, in view of the state of historiographical research, we chose to focus on three periods: the time of the $16^{\text {th }}$ and $18^{\text {th }}$ century and the so-called "century of capitalism", arbitrarily defined as taking place from the middle of the $19^{\text {th }}$ to the middle of the $20^{\text {th }}$ century. The concept of economic lag is emphasised as the starting point of the discussion. As this is an extremely complex research issue, the discussion will limit itself to the level of the most general points, that is, the comparison of the basic denominators of the economic dynamics, fulfilling the criterion of the long-term nature, which can be generalised as a historical constant. Our goal is to confront the realisations of the individual research analyses from the viewpoint of the long-term perspective and unify them in terms of the problem/interpretative common denominators. With such a concept this discussion will unavoidably be exposed for the possible (justified!) criticism due to the generalisation and simplification of the historical processes at the Slovenian level, let alone the narrower regional or even local levels. However, there is a reason for such a concept of the discussion. As it is, we aim to encourage further debate, reconsiderations, and ultimately perhaps also the emergence of new concepts of the research thematisation of the long-term tendencies and circumstances of the economic development in the Slovenian territory in the modern age.

Like other historiographies, Slovenian economic historiography is based on the supposition of a constant, almost linear and gradual progress. ${ }^{4}$ That means that it is based on the principle of continuity. At the same time the principle of dissimilarity in the process dynamics is integrated into this model. That means that the supposition of constant progress is also accompanied with the qualitative definition: that in case of the Slovenian economic development we are dealing with lag. The term of lag itself, or, more precisely, the concept of the relative economic backwardness ${ }^{5}$, denotes the diverging dynamics of the

$4 \quad$ For more information about this see Lazarević, Žarko (2012): Identitete in imena gospodarskega zgodovinopisja $\mathrm{v}$ Sloveniji [Identities and Names of Economic Historiography in Slovenia]. In: Ekonomska $i$ ekohistorija, VIII/8, pp. 116-136.

5 The concept has otherwise been used by the economic historian Alexander Gerschenkron for the time of the $19^{\text {th }}$ century in order to explain the various starting points before the entry of certain regions/states into the industrialisation process. In light of the supposition that the regional differences in the levels of economic development in Europe are older and thus reveal themselves as something permanent, the use of Gerschenkron's concept is completely appropriate. For more detailed information see Gerschenkron, Alexander 
economic development, which become apparent from a comparative analysis with the immediate or more remote surroundings. In this way we are opening the issue of the relative regional differences in the European space in the historical perspective, as it is certain that the concept of the economic lag addresses the relationship between the levels of the economic development in Slovenia and Western Europe. The dynamics and forms of the Western European economic development represent a model to which the economic development elsewhere is compared. By introducing the concept of lag we also introduce a few teleological elements into the interpretation of economic history, as in this way we supposedly know the goal towards which history is headed. Societies which are identical or similar to the Western European model with regard to the economic structure, developmental dynamics and institutional economic forms are seen as modern, while all others are considered as backwards. Such a division becomes even deeper in the most recent industrial age and acquires additional manifestations in comparison with the preceding periods.

The thesis about the lag involved in the Slovenian economic development is generally accepted. Moreover, it has often been completely clearly substantiated in the theoretical and empirical sense - also in different periods, but most notably for the $16^{\text {th }}$ century, $18^{\text {th }}$ century, and for the period of the $19^{\text {th }}$ or $20^{\text {th }}$-century industrialisation or the century of capitalism. As far as the $16^{\text {th }}$ century is concerned, we cannot overlook the in-depth analyses carried out by Ferdo Gestrin $^{6}$, who presented this time as a period of confrontation and intertwining of the old and vanishing forms of medieval institutions and the emerging modern times, with the first outlines of the new views and forms of the economic and social life. Gestrin completely unequivocally defines the end of this period as an open manifestation of the economic lag process. In these definitions Gestrin is also joined by Jože Šorn, who placed his book on the beginnings of industry in the time of the $18^{\text {th }}$ century and the pre-March period. The message of Šorn's monograph is clear, and already Jasna Fischer and Peter Vodopivec brought

(1979), Economic Backwardness in Historical Perspective. Belknap Press of Harvard University Press, pp. 5-30.

$6 \quad$ Gestrin, Ferdo (1991):, Slovenske dežele in zgodnji kapitalizem [Slovenian Lands and Early Capitalism]. Ljubljana: Slovenska matica. Apart from this fundamental work we also have to mention a series of three articles, published by Ferdo Gestrin in 1968, in which he provided a synthetic overview of the basic economic processes in the Slovenian territory from the $16^{\text {th }}$ and until the end of the $19^{\text {th }}$ century, later also published in various other forms. See Gestrin, Ferdo (1969): Oris gospodarstva na Slovenskem v obodobju zgodnjega kapitalizma [Outline of Economy in Slovenia in the Period of Early Capitalism]. In: Kronika, 17, No. 1, pp. 1-7; Gestrin, Ferdo, Oris gospodarstva na Slovenskem v obdobju agrarne revolucije in prevlade manufakturne proizvodnje [Outline of Economy in Slovenia in the Period of the Agrarian Revolution and Domination of Manufacture Production]. In: Kronika, 17 (1969):, No. 2, pp. 65-71; Gestrin, Ferdo (1969): Oris gospodarstva na Slovenskem v prvem obdobju kapitalizma [Outline of Economy in Slovenia in the First Period of Capitalism]. In: Kronika, 17, No. 3, pp. 129-137. 
the attention to it in their foreword written on the occasion of the posthumous publication of Šrn's book in 1984. The presented empirical materials attest to the slowness of the economic structural changes (as the relationship between the agrarian and non-agrarian part of the economy) in the Slovenian territory, leading to the increasing gap between the development dynamics of Slovenia and other provinces of the Habsburg Monarchy, especially in comparison with the Czech lands. Furthermore, Šorn's thesis is that in the first half of the $19^{\text {th }}$ century the developmental differences even deepened. ${ }^{7}$ The discourse of lag also remains an important interpretative aspect in the evaluation of the economic development of the Slovenian territory in the $19^{\text {th }}$ and $20^{\text {th }}$ century. Thus we can underline the complex study carried out by Mojca Novak, who successfully integrated the exploration of Slovenian industrialisation into a wider theoretical comparative context from the viewpoint of the sociological definition of the problem. ${ }^{8}$ The regional economic differences in the Habsburg Monarchy in the second half of the $19^{\text {th }}$ century at the level of individual provinces were presented convincingly by Andrej Pančur. His study also confirms the thesis of the below-average development of the Slovenian provinces, lagging behind with regard to the implementation of the industrialisation processes. ${ }^{9}$ Žarko Lazarević has underlined the disproportionate dynamics of the economic development by referring to gross domestic products. In a special study he focused on the long-term economic development of Slovenia from the middle of the $19^{\text {th }}$ to the end of the $20^{\text {th }}$ century in the European perspective, i.e., through the relations between the gross domestic product levels of Slovenia and other European countries. On the basis of the results it can be summed up that Slovenia, in the historical perspective of the last two centuries, lags behind the countries of the North-Western Europe, that is, behind the countries where the unstoppable progress of the industrial revolution first started. However, Slovenia has kept its development at approximately the same level as the Southern European or Mediterranean countries. However, if we look towards the East, it becomes apparent that especially in the $20^{\text {th }}$ century Slovenia has increased its economic

FischeR, Jasna, Vodopivec, Peter (1984): O avtorju in njegovem delu [About the Author and His Work]. In: ŠORN, Jože, Začetki industrije na Slovenskem [Beginnings of Industry in Slovenia]. Maribor: Založba Obzorja, p. 6.

$8 \quad$ Novak, Mojca (1991): Zamudniški vzorci industrializacije. Slovenija na robu Evrope [Patterns of Industrialisation Lag. Slovenia at the Edge of Europe]. Ljubljana: Znanstveno in publicistično središče.

9 Pančur, Andrej (2002): Ekonomska vloga Avstro-Ogrske v evropskem prostoru s stališča modernizacijskih procesov in položaj posameznih dežel v njej [Economic Role of Austro-Hungary in the European Space from the Viewpoint of the Modernisation Processes and the Position of Individual Provinces in It]. In: Prispevki za novejšo zgodovino, 42, No. 2, pp. 17-31. 
advantage in comparison with the other former communist countries of the Eastern Europe and the Balkans. ${ }^{10}$

Thus the aforementioned studies (and not only these) unequivocally register the dichotomy between the economic-developmental dynamics between Slovenia and its immediate north-western surroundings. It is also obvious that long-term developmental characteristics are involved. Thus the words of the American economist John Galbraith - that in order to understand the economic position of individual countries it is very important to know where they were in the distant past - are also very true in case of the Slovenian economic development. ${ }^{11}$ The awareness of the historical bases for the various economic stages in the European space has been present for a long time. This realisation was especially relevant for the thematisation of the process of industrialisation and its territorial expansion. Researchers promptly established that at the outset, on the same timeline, individual countries were in different positions, stemming from the centuries of differences in their developmental paths in the context of the feudal social and economic system. ${ }^{12}$ The researchers especially emphasise the various levels of productivity in agriculture due to the different technologies of production, consequently resulting in just as diverse potentials for economic growth. ${ }^{13}$ An important emphasis has also been placed on other dissimilarities, for example the question of ownership rights (that is, the capacity to transform the pre-capitalist forms of ownership rights

$10 \quad$ Lazarević, Žarko (2007): Sočasnosti slovenskega gospodarskega razvoja [Contemporaneity of Slovenian Economic Development]. In: Zgodovinski časopis, 61, No. 3-4, pp. 393-410.

11 Galbraith, John K (1980): The Nature of Mass Poverty. London: The Penguin Books, pp. 17-18.

12 Chirot, Daniel (1989): Causes and Consequences of Backwardness. In: Chirot, Daniel (ed.), The Origins of Backwardness in Eastern Europe. University of California Press, pp. 1-13. See also Hoffmann, Philip, Jacks, David, Levin, Patricia, Lindert, Peter (2002): Real Inequality in Europe since 1500. In: The Journal of Economic History, 62, No. 2, pp. 322-355. The regional disparities from the viewpoint of salaries and prices were presented by Allen, Robert (2001): The Great Divergence in European Wages and Prices from Middle Ages to the First World War. In: Explorations in Economic History, 38, pp. 411-447.

13 Clark, Gregory (1987): Productivity Growth without Technical Change in European Agriculture before 1850. In: The Journal of Economic History, 47, No. 2, pp. 419-432. Although his article provoked a resolute objection from John Komlos, who criticised its insufficient empirical comparative foundations as well as clumsily extrapolated conclusions, the fact of the apparent differences in the productivity of agriculture in the European dimensions nevertheless exists. For more details see Komlos, John (1988): Agricultural Productivity in America and Eastern Europe. A Comment. In: The Journal of Economic History, 48, No. 3, pp. 655-664, and the response by Clark, Gregory (1989): Productivity Growth Without Technical Change in European Agriculture. Reply to Komlos. In: The Journal of Economic History, 49, No. 4, pp. 979-991. 
into capitalist rights), personal freedoms, or role and structure of the cities, to mention but a few categories. ${ }^{14}$

Regardless of the fact that when emphasising the three comparative overviews from the Slovenian economic history we are dealing with three different historical contexts, the continuity of the economic lag is the very phenomenon that brings together the interpretations of the Slovenian economic history from the $16^{\text {th }}$ and until the end of the $20^{\text {th }}$ century. The interpretative approaches of the economic history in the second half of the previous millennium are also brought together by the fact that with the exception of the second half of the $20^{\text {th }}$ century Slovenia was a traditional society, in which agriculture was an irreplaceable economic sector. Precisely the changing percentage of the peasant population is one of the key indicators of the developmental economic dynamics, average productivity and economic structure.

The classic economic theory states that four demands have to be met in order to ensure economic development: a society must have suitable human and natural resources as well as the accumulation of capital and technology at its disposal. These four pillars of development function in a reciprocal manner. A registered lag in combination with slow economic restructuring based on the model of economically superiorly developed environments places a certain (also Slovenian) environment in the framework of the economically and theoretically defined model of poverty in the long-term. ${ }^{15}$ If we enter this circle in the field of the slow accumulation of capital, then we can detect the lack of considerable investments in technology, resulting in low labour productivity. On the basis of the low average labour productivity or low efficiency of the economy as a whole, high population income cannot be ensured. The low average level of the population income is barely enough for survival, therefore hindering the demand, considerable savings and investments, which, in turn, leads to slow accumulation of capital. Thus the circle is complete. From all of the above the reciprocity of the individual developmental categories is completely obvious. On this basis we can conclude that technology or the achieved technological level determines the production structure of a certain society/economy, structure of

14 In this sense the following in-depth study of European agrarian systems is very illustrative: Brenner Robbert, Economic Backwardness in Eastern Europe in Light of the Developments in the West. In: Chirot (ed.), The Origins of Backwardness in Eastern Europe, pp. 15-52. For the purposes of this discussion the following work should also be consulted: Brenner Robert (1976): Agrarian Class Structure and Economic Development in Pre-Industrial Europe. In: Past \& Present, 70, pp. 30-75. From the viewpoint of the Central and Eastern Europe and agrarian relations, a clear analysis of European regional differences in the pre-industrial age was given by Gunst, Peter, Agrarian System of Central and Eastern Europe. In: Chirot (ed.), The Origins of Backwardness in Eastern Europe, pp. 53-91.

15 Samuelson, Paul, Nordhaus, Paul -William (2002): Ekonomija [Economy]. Ljubljana: GV Založba, pp. 542, 544.

Vol. 12, No 2, 2015: 61-88 
the regional/international commercial exchange, and thus also the position in the regional/international division of labour. ${ }^{16}$

Apart from the lag, as defined by the aforementioned authors, the time periods under consideration also share their process characteristics. In accordance with the modern distinctions between the models of economic development we can introduce into our discussion the moments of the proto-industrial and industrial society or the processes of proto-industrialisation and industrialisation, coinciding with the transition from the feudal economic system to the capitalist system. If there are no dichotomies as far as the definition of industrialisation or industrial society is concerned, this is not so in case of the concept and interpretative scheme of proto-industrialisation. The concept of proto-industrialisation, which has taken firm root in the economic-historical science, was outlined by Franklin Mendels on the basis of his own research. ${ }^{17}$ To sum it up very briefly, Mendels saw proto-industrialisation as a stage in the development of the modern economy based on industry, taking place in the context of the completely dissolved or dissolving feudal connections. With the concept of proto-industrialisation Mendels denoted the processes when in the rural areas the peasant craft production (as a supplementary or exclusive activity) strengthened either individually or in the context of the putting-out system. This was a widespread phenomenon in the various regions of Europe. Through trade relations this kind of production integrated the peasants into the market, market relations and division of labour at the regional, national, and also international level apart from the mere agricultural production and breeding. The process of proto-industrialisation involved the commercialisation of the agricultural craft knowledge and technology, which was supposedly present in the rural areas due to the dominant principle of the self-supply of these areas or the principle of the previous self-sufficiency of agricultural economies. The labour force price, significantly lower due to the agriculture as the primary activity, supposedly represented a competitive advantage in comparison with the craft-guild production. The processes of proto-industrialisation also triggered the processes of economic growth, accumulation of capital, business skills, and agricultural progress. Furthermore, Mendels also ascribed the process of proto-industrialisation with having far-reaching social implications from the reciprocal connections between the intensity of the proto-industrialisation processes and the changes of the population number, family structure, fragmentation of land, and increase in dependent labour (not to say proletarisation) in the rural areas. Proto-industry allegedly also started

\footnotetext{
16 Sočan, Lojze (1978): Pot v gospodarsko razvitost [Path Towards Economic Development]. Ljubljana: Delavska enotnost, p. 37.

17 Mendels, Franklin F. (1972): Proto-Industrialization. The First Phase of the Industrialization Process. In: The Journal of Economic History, 32, No. 1, pp. 241-261.
} 
solving the Malthusian trap, which was ultimately broken by industrialisation. With economic growth and the increasing income of the peasant population the processes of proto-industrialisation contributed to the long-term strengthening of demand or consumption, which became the driving force of industrialisation in the modern sense of the word.

Just like any other model, the Mendels's concept of proto-industrialisation has faced many objections and corrections due to its aspirations for general validity. ${ }^{18}$ Doubts have stemmed from new research, questioning or further developing many suppositions of Mendels's, especially in the social field. At the level of the foundations the critics of the proto-industrialisation concept were compatible with Alexander Geschenkron, who emphasised the divergence of the paths taken by the individual regions/provinces towards industrialisation and the lack of a certain general model of industrialisation in Europe. ${ }^{19}$ The criticism of the proto-industrialisation model stemmed from the extensive empirical materials from various parts of Europe. These detailed studies showed that just like we cannot speak about a uniform pattern during the process of industrialisation, proto-industrialisation is hardly any different. Significant differences in the manifestations of proto-industrialisation were registered. The theorem of proto-industrialisation turned out to be a flexible process, resulting from the adaptation to the local social and economic contexts. ${ }^{20}$ The principle of discontinuity was built into the concept of proto-industrialisation as well. The term »de-industrialisation" was introduced to denote the process when the proto-industrialisation phenomena stopped (due to various economic, political or social reasons) and the supplemental production was abandoned in certain areas. Thus these areas became more dependent or were once again completely dependent on agricultural production. The automatic transition of the proto-industrial production to the modern industrial organisation of acquiring goods was therefore questioned. The arguments were clear. The empirical materials did not provide enough arguments to give the

18 This is also because we historians, in our focus on the details, are (un)righteously critical of the generalised models of interpreting the historical economic processes.

19 Gerschenkron, referenced work. See also the synthetic summary of the topical debates about the industrial revolution in Beaudoin, Steven M. (2000): Current Debates in the Study of the Industrial Revolution. In: OAH Magazine of History, 15, No. 1, pp. 7-13.

20 Mendels's concept of proto-industrialisation encouraged a lively discussion among economic historians. For more detailed viewpoints see, for example, Colleman, Donald C. (1983):, A Proto-Industrialization. A Concept Too Many. In: The Economic History Review, New Series, 36, No. 3, pp. 435-448; OGILVIE, Sheilagh C. (1995), Institutions and Economic Development in Early Modern Central Europe. In: Transactions of the Royal Historical Society, Sixth Series, 5, pp. 221-250. It is also recommended to take a look at the very informative collection of scientific texts, summing up the basic realisations about the theorem and manifestations of proto-industrialisation in Europe: Ogilvie, Sheilagh C. (ed.), Cerman, Mark (ed.) (2007): European Proto-Industrialization. Cambridge: Cambridge University Press.

Vol. 12, No 2, 2015: 61-88 
supposition of the automatic development of proto-industry into modern industry the character of general validity. ${ }^{21}$ Despite all of the scepticism the concept of proto-industrialisation still counts as a very useful analytical tool for the interpretation of the gradual restructuring of the economy in the three centuries from the $16^{\text {th }}$ to the end of the $18^{\text {th }}$ century, which the concept of proto-industrialisation encompasses in its temporal dimension. The essential contribution of the proto-industrialisation concept to the economic-historical science is that this concept transcended the interpretative simplifications of the economic development in view of the discontinuity of industrialisation in the $19^{\text {th }}$ century. ${ }^{22}$ With the presumption of proto-industrialisation processes industrialisation finally lost its revolutionary character and became a part of the gradualist interpretative pattern in the historical studies.

Thus Sidney Pollard (like many others before and after him) defined industrialisation as a long-term set of various social, economic, technological and organisational-administrative changes, and by no means as a sharp and swift transition from one economic paradigm to another. At this point we have to emphasise that despite industrialisation traditional social sectors were preserved as well (craft industry, peasant craft production as well as small agricultural lands) simultaneously with the modern industrial factory compounds, mines, means of transport, capitalist agricultural facilities, etc. ${ }^{23}$ Traditional sectors may have operated in the context of market rules, but they did not fit into the capitalist economy completely. ${ }^{24}$ They remained at the

${ }^{21}$ See, for example, a very illustrative discussion Hudson, Pat, Proto-Industrialization in England, In: Ogilvie (ed.), Cerman (ed.), European Proto-Industrialization, pp. 49-66, referring to the work Colleman, A Proto-Industrialization, pp. 435-448, who, in his criticism of the proto-industrialisation concept, emphasised the insufficient empirical validity of the supposition with regard to the progression from proto-industrialisation to industrialisation.

22 Walton, John (1987): Theory and Research on Industrialization. In: Annual Review of Sociology, 13, pp. 89-108 (100).

23 Pollard, Sidney, The Industrial Revolution - an overview. In: Teich, Mikulaš, Porter, Roy (1996): The Industrial Revolution in National Context. Cambridge: Cambridge University Press, 1996, pp. 371-387.

24 Economic historians tried to explain this kind of structural characteristics - when two sectors co-exist (a relatively small, modern sector, depending on foreign demand; and the dominant sector, based on domestic, local demand as well as on the self-sufficiency of economy) - with the so-called »dualist theory«, which was not especially far-reaching. They wanted to illustrate the conflicts in the economic environment, intensifying the opposition between the capitalist part of the economy and the dominant forms of pre-capitalist economy, and establish the general patterns of development. As we will find out later, the Slovenian experience in the $19^{\text {th }}$ century was not radically different from this. For more information about the beginnings of such approaches see Higgins, Benjamin (1956): The "Dualistic Theory« of Underdeveloped Areas. In: Economic Development and Cultural Change, 4, No. 2, pp. 99-115. The application of dualist development, spreading from the economic sphere to the whole of society, has been used more than once, for 
brink of capitalist economy, if we refer to Braudel's differentiation typology. ${ }^{25}$ Another contribution by Pollard is also noticeable in the conceptualisation of industrialisation: because of the realisation that the process of industrialisation differed in its structure and speed in the various regions of the national economic spaces, he emphasised that the research activities should focus on the regional aspects rather than on the national aspects when studying the origin and development of industrialisation. ${ }^{26}$

The long-term changes in the structure and ways of the production of goods outside of the agricultural branches can also be shown schematically. The following table analyses the changes taking place in the non-agrarian production in the time of the profound transition from the feudal economic structures to the modern capitalist economy. The variables of the transformation are defined from the viewpoint of the spatial and locational placement of non-agrarian production, status of the participants in the production process (employees), characteristics of the working cycle rhythm, supervisory and administrative functions, ownership of the production factors, and, finally, the branch aspects.

On the basis of the foundations presented in Table 1. we can attempt to define the basic developmental characteristics of the economic development in the Slovenian territory in the time of the transition from feudalism to the capitalist economic system. In this regard we will sum up the thesis of Lojze Sočan as an interpretative framework: that the achieved technological level determined the structure of production, commercial exchange, and thus also the position in the regional division of labour. We will carry out an overview on the basis of certain variables with the potential to illustrate the characteristics of the development during the transition from feudalism to capitalism and towards the industrialisation in the modern times. While we undertake this we will not pay any attention to the issues of the general environment (political situations, economic policies, international circumstances, etc.), because we are limited in terms of space. However, this environment is constantly present in the background of the ongoing changes that we present as characteristic features.

example by Ivan Berend (Berend, Ivan, (2005): History Derailed. Central and Eastern Europe in the Long Nineteenth Century. Berkeley - Los Angeles: University of California Press), who emphasises the dualist polarisation of the social and economic development of the Eastern European parts in the $19^{\text {th }}$ century.

25 See the summary of his concepts: Braudel, Fernand 2010): Dinamika kapitalizma [The Dynamics of Capitalism]. Ljubljana: Sophia.

26 Pollard, Sidney (1973): Industrialization and the European Economy. In: The Economic History Review, New Series, 26, 1973, No. 4., pp. 636-648 (p. 646). The quoted article sums up the basic conceptual outlines of the regional research approach, presented by Pollard in much detail at the level of the concept and empirical substantiations in the book which has acquired the status of the fundamental work addressing the issue of the European industrialisation. See Pollard, Sidney (2002): Peaceful Conquest. The Industrialization of Europe. 1760-1970. Oxford: Oxford University Press. 
Table 1: Structure of production in the pre-industrial and industrial time ${ }^{27}$

\begin{tabular}{|l|l|l|l|}
\hline Place of production & $\begin{array}{l}\text { Craft production in the } \\
\text { Middle Ages }\end{array}$ & \multicolumn{1}{|c|}{$\begin{array}{c}\text { Proto-industrial } \\
\text { production }\end{array}$} & $\begin{array}{c}\text { Modern capitalist } \\
\text { industrial production }\end{array}$ \\
\hline Workplace & $\begin{array}{l}\text { Craft industry master's } \\
\text { workshop }\end{array}$ & Pearal areas & $\begin{array}{l}\text { Locations near } \\
\text { accessible sources of } \\
\text { energy or raw materials }\end{array}$ \\
\hline Employees & Master and apprentices & Peasant family & Factory \\
\hline Work cycle & Continuous & $\begin{array}{l}\text { Alternating with } \\
\text { agricultural chores }\end{array}$ & $\begin{array}{l}\text { Continuous and } \\
\text { coordinated }\end{array}$ \\
\hline $\begin{array}{l}\text { Administrative } \\
\text { functions }\end{array}$ & Master & $\begin{array}{l}\text { Merchant/central agent } \\
\text { (entrepreneur) }\end{array}$ & Capitalist businessman \\
\hline $\begin{array}{l}\text { Owner of raw } \\
\text { materials }\end{array}$ & Master & Peasant or central agent & Capitalist businessman \\
\hline $\begin{array}{l}\text { Owner of production } \\
\text { means }\end{array}$ & Master & Peasants (not always) & Capitalist businessman \\
\hline Owner of products & Master & $\begin{array}{l}\text { Merchant/central agent } \\
\text { (entrepreneur) }\end{array}$ & Capitalist businessman \\
\hline $\begin{array}{l}\text { Most prominent } \\
\text { branches }\end{array}$ & $\begin{array}{l}\text { Textiles and clothing } \\
\text { aeather industry Wood } \\
\text { Building industry Food }\end{array}$ & Textiles and clothing & No restrictions \\
\hline
\end{tabular}

With regard to the dynamics of changes in the Slovenian space the percentage of the peasant population is one of the most obvious indicators. Thus Gestrin, for example, states that in the end of the $16^{\text {th }}$ century almost $94 \%$ of all population of the Slovenian provinces lived in the rural areas. ${ }^{28}$ In view of this information we can state that for the same percentage of the population agriculture was the exclusive or primary economic activity. If Gestrin's statement is an estimate, the information dating back to 1910 is already far more reliable due to the well-developed statistical service. At that time around $67 \%$ of the population worked in agriculture. ${ }^{29}$ Realistic estimates for the time before

$27 \quad$ Table summed up according to Felloni, Giuseppe (1997): Profilo di storia economica dell'Europa. Dal medioevo all' eta contemporanea. Turin: Giappichelli, p. 157. Quoted in accordance with Massa, Paola, The Economy in Fifteen Century - Preconditions for European Expansion. In: Di Vittorio, Antonio (2006): An Economic History of Europe. From Expansion to Development. London - New York: Routledge, pp. 1-25 (16).

28 Gestrin, Slovenske dežele in zgodnji kapitalizem, p. 20.

29 FISCHER, Jasna (2005): Družba, gospodarstvo, prebivalstvo. Družbena in poklicna struktura prebivalstva na slovenskem ozemlju od druge polovice 19. stoletja do razpada 
World War II (because the census was not carried out in 1941) place this share at around $60 \% .^{30}$

The information about the percentage of the peasant population is seen as important by economic historians, without further substantiating this fact. It attests to the levels of economic growth and gross domestic product, specifying the relative position of an individual environment in the international/ inter-regional comparisons. Furthermore, this information also indicates very slow endogenous economic dynamics in the Slovenian space throughout the modern period. In three centuries the percentage of the peasant population in the Slovenian territory decreased by merely one third. As a comparison let us underline that in the countries representing the core of the Western Europe the percentage of the peasant population dropped below one half of the total population as early as in the first half of the $19^{\text {th }}$ century. For example, in the more developed parts of the Habsburg Monarchy the share of the peasant population at the turn of the $19^{\text {th }}$ century amounted to $30 \%,{ }^{31}$ which is even lower than the percentage in Slovenia before World War II. In Europe in 1870 forty years before the Slovenian $67 \%$ in 1910 - the following countries had the following percentages of the population working in agriculture: Great Britain $14 \%$, Belgium $17 \%$, the Netherlands $35 \%$, France $59 \%$, and Austria $64 \%$, to mention but a few. ${ }^{32}$ The differences are obvious and speak for themselves.

The comparatively low efficiency was another characteristic of agriculture. Already in the $16^{\text {th }}$ century agriculture had to face a challenge. It came across the limitations of the production factors in view of the contemporaneous technology (three-year rotation of crops, extensive grazing livestock production). The pre-modern age, when the agricultural yield could be improved by extending the arable areas, thus satisfying the increasing demand for food as a consequence of the population growth, was coming to an end. With the end of the internal colonisation the possibility for extensive production increase was exhausted. Since the $18^{\text {th }}$ century a gradual progress of agriculture began in accordance with the technical agrarian measures, aimed to increase the labour productivity.

The problem of agrarian overpopulation is closely connected with the low yield of the agricultural branches or the slowly increasing labour productivity. This was characteristic for the Slovenian space until as late as World War II. To put it simply, an imbalance existed between labour productivity in agriculture and the number of population. This imbalance resulted in the fragmentation of

Habsburške monarhije [Society, Economy, Population. Social and Vocational Structure of the Population in the Slovenian Territory between the Second Half of the $19^{\text {th }}$ Century to the Dissolution of the Habsburg Monarchy]. Ljubljana: INZ, 2005, p. 112.

30 Lazarević, Žarko (2009): Plasti prostora in časa. Ljubljana: INZ, p. 115.

31 Fischer, Družba, gospodarstvo, prebivalstvo, p. 112.

32 Broadberry, Stephan (ed.), O'Rourke, Kevin H. (ed.) (2010): The Cambridge Economic History of Modern Europe. 1. 1700-1870. Cambridge: Cambridge University Press, 2010, p. 149. 
the land structure in agriculture. Fragmented agricultural lands are the most characteristic example of economic lag. Because the economic growth was slow, land was an indispensable production factor (survival factor!) under the conditions where the population was increasing. Hence the constant pressure to divide the land, in so far as the authorities did not intervene. Therefore this involves an emphasis on the reallocation of the existing property and thus also the long-term weakening of the economic potentials of agriculture as a whole. The phenomenon started as early as in the $16^{\text {th }}$ century, continued in the $18^{\text {th }}$ century, ${ }^{33}$ and was no less topical even as late as in the $19^{\text {th }}$ century. ${ }^{34}$

Apart from the simultaneous principle of constancy or persistence of phenomena, the long-term perspective of the modern age until World War II also reveals two periods of notable discontinuity, when the re-agrarisation of the Slovenian space took place. The diminishing importance of non-agrarian activities in the economic structure is defined as re-agrarisation. Within the concept of proto-industrialisation this phenomenon is defined as de-industrialisation. At this point we can state that the development of the non-agrarian sector in the Slovenian space was in close correlation with the scope of external demand and other exogenous factors. Thus we claim that the significant fluctuations in the direction of the developmental tendencies were a consequence of the changing structure of external demand. As it is, through this relationship the basic economic dilemma of the Slovenian space in its relation to the international environment expresses itself. It has to do with the smallness of the economic national space and the consequently low domestic demand (a consequence of agrarian overpopulation!), which cannot fulfil the role of an exclusive driving force of the economic development in the long term. When the domestic demand was the dominant motive for economic development, the level of growth receded (re-agrarisation/de-industrialisation). The slackening economic development failed to accelerate the processes of economic de-feudalisation and transition into the capitalist economy, and later also industrialisation. Therefore it is not surprising that the fragmentation of economic subjects and lack of capital available for economic activities, which hindered the economic initiative, scope of business, defined the structure and lowered the international competitiveness of the Slovenian economic subjects, were permanent characteristics. Only companies able to develop a suitable economy of scope, especially thanks to the foreign demand as well as the capital and professional reliance on the foreign investors, could be competitive internationally.

Gestrin's research on the economic circumstances of the $16^{\text {th }}$ century reveals that the first point of discontinuity in the economic development (re-agrarisation, de-industrialisation) can be identified already at the end of that century.

33 Gestrin, Oris gospodarstva na Slovenskem v obdobju agrarne revolucije in prevlade manufakturne proizvodnje, pp. 65-71.

34 Lazarević, Plasti prostora in časa, pp. 106-113. 
Non-agricultural activities in the Slovenian space diminished as the European economic centre moved towards the Atlantic shores and the importance of the Italian space (Republic of Venice, which the trade flows were mostly oriented towards), receded. This also happened because of the general crisis resulting from the economic situation as well as due to the political and military changes. As it was, the Italian economic space or the demand there was the driving force of the service and proto-industrial activities in Slovenia. The scope of agricultural craft production as well as trade flows from and towards the Slovenian territory receded, and gradually the few operational manufactures stopped functioning as well. This was also related to the diminishing value of the bourgeois assets, which by no means contributed to the strengthening of the capital basis of the economy. Moreover, Gestrin reports that due to their strong capital foundations the Venetian merchants gradually pushed out the merchants in the Slovenian territory from the intermediation in the profitable trade in livestock from the Hungarian plains. Not only that: the Italian entrepreneurs gradually took over the initiative in other production activities as well, for example in the ironwork industry.

The stagnation and recession had direct consequences for further development. The economic pressure incentives to ensure a swifter transition into the capitalist economy were thus missing. The traditional feudal understanding of the social division of labour remained untouchable. With the growth of the non-agrarian sector the Slovenian space had to face a test of its capacity to transform the feudal economic and social structures. This process was slow as it was, especially in comparison with the European core and particularly in the field of property rights and personal dependence of peasants. The external manifestation of the changed circumstances was a significantly reduced number of guild complaints against the peasant craft production and peasant trade, which was also tolerated by the big landowners due to economic benefits. ${ }^{35}$ The role of craft guilds - the defenders of the feudal division of labour - in the monopolisation of the existing domestic market and regulation of the otherwise modest domestic demand (scarcity of urban population, self-sufficiency of agricultural economy) was not yet seriously threatened.

The $18^{\text {th }}$ century is deemed to be a period of intense changes with regard to the feudal structures in the context of the mercantilist and physiocratic doctrine and the state policies based on it. The centralised state undertook an active state intervention in the economy. The new economic doctrines prioritised the efficiency of economy due to the increasing level of knowledge and new technologies. Precisely for this reason the measures to ensure the liberalisation of economic activities (together with the simultaneously planned regulation) were adopted at this time. Important measures included those in the field of the regulation of economic activities of peasants (property rights, personal dependence, regulation of duties), who expanded their operations to the field

35 Gestrin, Slovenske dežele in zgodnji kapitalizem, pp. 35-80. 
of services (commerce, transport) and proto-industrial activities. The altered approach and general economic boom resulted in the growth of production in the Slovenian territory. This growth mostly stemmed from the rural areas, from the ranks of peasants. The growth was notable because of the planned acceleration of agricultural development and the renewed strengthening of agricultural craft production. These relations are clearly evident from the evaluation of Jože Šorn, who wrote, in his book on the beginnings of industry in the Slovenian territory, that in the second half of the $18^{\text {th }}$ century $29 \%$ of the production was allegedly contributed by the peasant craft production (otherwise unequally distributed throughout the Slovenian space), $25 \%$ by craft industry, $25 \%$ by manufactures and $21 \%$ by mining and ironworks. ${ }^{36}$

Therefore economic emancipation of the peasants (indication of the final de-feudalisation) already took place in the $18^{\text {th }}$-century proto-industrial period and was strengthened by the expansion of the scope of the economic activities in the rural regions in the context of agricultural and non-agricultural activities. According to Sorn we can illustrate the importance of the peasant production with the example of the production of canvas in Upper Carniola, which was significant even in the Austrian context. ${ }^{37}$ Furthermore, Šorn's conclusions suggest that the production growth in Slovenia was a direct consequence of the export demand. Šorn reconstructed the transportation routes through Trieste and Rijeka or towards the northern parts of the Habsburg Monarchy precisely. ${ }^{38}$ In Slovenia in the $18^{\text {th }}$ century we are thus dealing with the classic Pollard's regionally diverse economic structure, where an exportation type of proto-industrialisation was formed due to the production competitiveness.

Afterwards, in the $19^{\text {th }}$ century, the second discontinuity in the economic development - or the second "de-industrialisation" - of the modern times took place. Due to the set of international circumstances (the Napoleonic Wars) and the development of industrialisation in the North-Western Europe the external demand changed once again, as the Slovenian economy became uncompetitive in the international sense. Proto-industrial activities gradually lost their footing. The competition of foreign industry was simply too stiff, at first in the foreign markets and then in the domestic market as well. The process became even swifter as the railway network was built. At that time the fundamental lag in the economic development dynamics became evident. The railroad is an appropriate example to illustrate the extent of the relative lag or the differences in the starting positions on the threshold of industrialisation. In Great Britain the railroad was a consequence of industrialisation, while in France and Germany it

\footnotetext{
36 Šorn, Začetki industrije na Slovenskem, pp. 62-63.

37 It is interesting that this activity was even mentioned in the overviews of the European history as an example of a significant scale and economic importance for the local area as well as for the wider region. See Di Vittorio, An Economic History of Europe, p. 119.

38 Šorn, Začetki industrije na Slovenskem, pp. 62-69.
} 
was, for example, an integral part or the driving force of industrialisation. The situation in the Eastern Europe, including Slovenia, was completely different. There the railroad was barely a harbinger of industrialisation, ${ }^{39}$ connecting these areas with the wider transportation and economic flows. Industrialisation itself, however, did not begin until a few decades after the railways had been built. The railroad was constructed with foreign capital and foreign knowledge (as well as because of foreign strategic needs), and its influences on the existing economic structure were by no means singularly positive. The railways exhibit the same lag of approximately half a century between the construction of the first lines, built to satisfy the strategic requirements of the Habsburg Monarchy, and the network intended to address the local needs. ${ }^{40}$

With the loss of regional competitiveness the development model in the Slovenian territory changed once again. With stagnation and gradual disappearance of the proto-industrial production and service activities (transportation) the process of re-agrarisation reoccurred. The process of the second »de-industrialisation", as the decline of the peasant craft production is defined, was thus triggered. At least Carniola, as the central Slovenian province, had a more evidently agrarian character in the second half of the $19^{\text {th }}$ century in comparison with the preceding period. ${ }^{41}$ With re-agrarisation the domestic economic incentives for a swifter transition to the capitalist economic system were missing once again, and the life span of what were otherwise already dissolving feudal structures was extended even further. When the process of de-feudalisation occurred also formally after 1848 , this was a consequence of an arbitrary political decision, dictated by the internal-political situation as well as by the wish to ensure the economic modernisation of the Monarchy. At this time industrialisation had already become imperative - quite the opposite from the countries of the North-Western Europe, where de-feudalisation had

39 Pollard, Industrialization and the European Economy, pp. 646. O, An Economic History of Europe, p. 119. Šorn, Začetki industrije na Slovenskem, pp. 62-69. Pollard, Industrialization and the European Eco

40 See Mohorič, Ivan (1968), Zgodovina železnic na Slovenskem [History of Railways in Slovenia]. Ljubljana: Slovenska matica.

41 Gestrin, Oris gospodarstva na Slovenskem v prvem obdobju kapitalizma (do 1918), p. 131. The process of "re-agrarisation« was not only a Slovenian peculiarity, nor is it unusual. Researchers have also detected similar processes, taking place elsewhere in Europe. As individual areas started entering the European economic space more intensively and the industrialisation began, the importance of agrarian activities in the economic structure often became stronger once again. In a way this was an adaptation to the new circumstances, as the non-agrarian sector was inefficient and thus uncompetitive in comparison with the industrial production, while the international agricultural product market was open. For more information about these processes see Turnnock, David, The Economy of East Central Europe. London: Reutledge, 2006; BEREND, History Derailed. Central and Eastern Europe in the Long Nineteenth Century. 
concluded organically as long as several decades earlier. ${ }^{42}$ For the Slovenian territory the process of de-feudalisation implied that the capitalist economic and social institutions would be imported. It was a transition which involved a political process from the top, from outside, and did not encompass many changes resulting from the endogenous economic dynamics. The new imported institutional framework had to be filled with domestic contents. The Slovenian manifestation of capitalism had to be defined. Thus a process of the adoption and adaptation of institutions and innovations of the capitalist economy to the Slovenian environment, lasting for several decades, was initiated.

With re-agrarisation domestic demand became the driving force of the economic growth. Due to the structural crisis of agriculture the Slovenian space was caught in the vicious circle of poverty, low income, meagre savings, modest investments and deficient technological level. Agrarian overpopulation and redistribution of the existing social wealth in the form of the fragmentation of agricultural property once again became topical. The re-agrarisation of the Slovenian space corresponds to the thesis that no direct connection necessarily exists between the developed proto-industrial activities and industrialisation. In such cases industrialisation had to begin completely anew. Re-agrarisation also attests to the level of entrepreneurship, which failed to perform its much-needed role as an agent of economic changes at this time.$^{43}$ For the second half of the $19^{\text {th }}$ century a dualist economic structure was characteristic for the Slovenian space and two economic sectors co-existed: the majority traditional (peasant and craft) sector and the capitalist sector. The former, traditional sector depended on domestic demand. As this demand was modest due to the vicious circle of poverty, the economic growth was modest as well. Until the 1880 s or 1890 s the traditional sector operated mostly on the verge of the capitalist system. ${ }^{44}$ Due to the expansion of the capitalist economy in the wider environment, the traditional sectors were constantly threatened. Thus the protective rhetoric strengthened again, just like at the end of the $16^{\text {th }}$ century. Both periods share the efforts for the "protection of domestic labour" (Valentin Suppan) and for the interventionist delimitation between the traditional sectors and capitalist

$42 \quad$ For more information about the process of the transition to the capitalist economy and industrialisation as well as its territorial dynamics in the Western Europe see Damsgaard, Hansen (2001): European Economic History. From Mercantilism to Maastricht and Beyond. Copenhagen: Copenhagen Business School Press.

43 In the economic history much attention has been paid to entrepreneurship as the driving force of the accelerated economic growth and economic innovation, also when explaining the dynamics of industrialisation. Entrepreneurship and its importance was introduced into the science of economy by Joseph Schumpeter, and later this aspect has also asserted itself in the economic historiography. See More, Charles (2000): Understanding the Industrial Revolution. London: Routlege, 2000, pp. 19-23.

44 Of the newer overviews of the economic history in the second half of the $19^{\text {th }}$ century in Slovenia see Slovenska novejša zgodovina (2005): Ljubljana: Inštitut za novejšo zgodovino, Mladinska knjiga, pp. 72-92. 
economy. ${ }^{45}$ In the $19^{\text {th }}$ century the environment structured in this manner was also unable to defend itself from the anti-capitalist rhetoric or ideology.

The domestic capitalist sector represented little threat to domestic agriculture or craft industry - after all, it was modest and completely dependent on the export demand. Ever since the beginning it had been established with the foreign markets in mind and was thus internationally competitive and based on modern technology. Three sectors were most prominent: textile industry ${ }^{46}$, ironwork industry ${ }^{47}$, and coal industry. ${ }^{48}$ The capitalist sector was encouraged by foreigners, and it was based on foreign initiative, capital and knowledge. Due to its meagre scope (around ten companies) the capitalist sector was unable to change the general development model and influence the type of the Slovenian industrialisation in the $19^{\text {th }}$ century. It was incapable of encouraging the export type of industrialisation. None of the economic sectors in the Slovenian space asserted themselves as the leading industry, if we use Rostow's term from his stages of economic growth. ${ }^{49}$ Simply put, in the Slovenian space no branch of industry had a strong enough development dynamic to encourage the growth of the wider economic and regional environment. Therefore no economic sectors or branches of industry existed capable of securing the path which the exportation capitalist sector (industrial or agricultural) ensured in Scandinavia, for example. ${ }^{50}$

$\overline{45}$ See Lazarević, Žarko (1996), Friedrich List. Spurensuche in Slowenien. In: Wendler, Eugen (ed.). "Die Vereinigung des europäischen Kontinents". Friedrich List - Gesamteuropäische Wirkungsgeschichte seines ökonomischen Denkens. Stuttgart: Schäffer-Poeschel, pp. 529-539. One of the most concise substantiations from the viewpoint of the national-economic space was given by Valentin Supan (see SUPAN Valentin C., (1869): Schutz der heimischen Arbeit. Laibach; Supan, Valentin C (1876): Reflexionen ueber die oesterreichische Handelspolitik und Ideen, wie es bald besser werden kann. Laibach, 1876; Supan Valentin C. (1877): Oesterreichs Volkswirtschaft - Handelspolitische Schriften mit Bezug auf die Zollverhandlungen mit Deutschland und Wendung der Handelspolitik am ganzen Kontinent England gegenueber. Laibach; Supan Valentin C. (1876): Politična ekonomija in politika [Political Economy and Politics]. In: Slovenski narod, 49, 1 March 1876.); and for the area of agriculture Krek, Janez Evangelist (1895): Črne bukve kmečkega stanu. Jedro kmečkega vprašanja [Black Books of the Peasant Class. The Core of the Peasant Question]. Ljubljana.

46 Kresal, France (1969): Vloga in pomen tekstilne industrije v industrializaciji 19. stoletja na Slovenskem [The Role and Importance of Textile Industry in the $19^{\text {th }}$ Century Industrialisation in Slovenia]. In: Kronika, 17, No. 2, pp. 85-91.

47 Mohorič, Ivan (1969): Dva tisoč let železarstva na Gorenjskem [Two Thousand Years of Ironwork Industry in Gorenjska]. Ljubljana: Mladinska knjiga.

48 Mohorič, Ivan (1978):, Problemi in dosežki rudarjenja na Slovenskem [Problems and Achievements of Mining in Slovenia]. Ljubljana: Založba Obzorja.

49 Rostow, W. W. (1959): The Stages of Economic Growth. In: The Economic History Review, New Series, 12, 1959, No. 1, pp. 1-16.

50 Gustafsson, Bo (1996): The Industrial Revolution in Sweden. In: Teich, Porter, The Industrial Revolution in National Context, pp. 201-225. 
The Slovenian economic development in the $19^{\text {th }}$ century was therefore based on domestic demand and consequently very slow due to the structural characteristics of the dominant part of the economy (percentage of peasant population, purchase power). Without the modernisation of agriculture - that is, increased productivity and income growth of the peasant population - swifter industrialisation could not take place. ${ }^{51}$ Faster economic growth cannot occur until the population keeps investing the majority of its labour into securing its basic existence. The situation in agriculture stabilised in the $1880 \mathrm{~s}^{\text {and }} 1890 \mathrm{~s}^{52}$ With the strengthening of the purchase power the domestic demand started more actively encouraging the transition of the traditional economic sectors into the capitalist forms of production, especially in the fields with low technological complexity. ${ }^{53}$ The domination of the capitalist economy in the Slovenian space occurred in the Yugoslav context after 1918. Just like before, in the $16^{\text {th }}$ and $18^{\text {th }}$ century the driving force of the economic growth and scope of the capitalist sector was foreign demand, this time in the form of the Yugoslav market and protectionist economic policy. ${ }^{54}$ Textile industry expanded most evidently. In the comparative sense this means that the type of industrialisation in the interwar period was still based on the technologically less demanding level. Thus Slovenia took the final step towards the industrial character of economy when the lands in the core of Europe had already been in the process of technological transformation involving the introduction of modern scientific achievements into industrial production processes for almost five decades. ${ }^{55}$ In the period between the two world wars Slovenian industrialisation can thus be defined with the parameters of the $19^{\text {th }}$ century, when the investments in the physical capital were essential for the encouragement of economic growth and technological transformation.

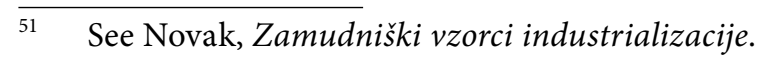

52 The results of the cumulative slowness with regard to the growth of the productivity in agriculture, reduction of the level of agrarian overpopulation (emigration!), growth of savings (credit cooperatives) and growth of purchase power despite the same level of income due to the system of cooperatives became apparent. For more information see Lazarević, Žarko (1998): Slovensko kmetijstvo od zemljiške odveze do druge svetovne vojne [Slovenian Agriculture from the Abolishment of Serfdom to World War II]. In: Gliha, Slavko (ed.), Kmetič, Ivanka (ed.), Koruza, Boris (ed.), Marinček, Lili (ed.), Zbornik ob 100-letnici Kmetijskega inštituta Slovenije. Ljubljana: Kmetijski inštitut Slovenije, pp. 13-30.

53 For the outline of the situation at the turn of the $19^{\text {th }}$ century see Brezigar, Milko (1918): Osnutek slovenskega narodnega gospodarstva [Outline of the Slovenian National Economy]. Celje: Omladina/Zvezna tiskarna, 1918.

54 For more information about the changes in the society and economy in the interwar period see Lazarević, Žarko (2013): Družba in gospodarstvo med obema vojnama. (Vprašanja ravni modernizacij) [Society and Economy in the Interwar Period. (Questions regarding the Modernisation Level)]. In: Zgodovinski časopis, 67, No. 1-2, pp. 110-134.

55 Gl. Damsgaard (2008), European economic history, pp. 155-188; Goldin, Claudia, Katz, Lawrence F., The Race between the Education and Techonology. Harvard University Press, pp. $1-8$. 
In conclusion of this discussion we can state a few final inferences or theses, summing up the characteristics of the economic transition from feudalism to capitalism in Slovenia in the modern period:

1) Slovenian space was permanently on the verge of the European processes of transformation of the feudal economic system into a capitalist economy.

2) External demand was the driving force of structural economic changes, as domestic demand could not carry out its role as the agent of the economic restructuring due to the low level of income. The dependence on domestic demand lengthened the process of changes in economy considerably and preserved or expanded the dimensions of the lag.

3) Slovenian economy and society entered these processes with a lag of several decades and with significant discontinuities manifesting themselves as re-agrarisation or de-industrialisation in the proto-industrial interpretative concept.

4) In the time of the discontinuity re-agrarisation the reallocation of the existing property took place, manifesting itself as the fragmentation of agricultural property. The fragmented agricultural property expressed itself as the most characteristic example of the relative economic backwardness.

5) Foreign entrepreneurs were the decisive proponents of change, introducing capital, market, business and administrative knowledge as well as technologies in the Slovenian space.

6) The smallness of the economic national space was a restrictive factor. It resulted in the fragmented structure and lack of capital available for economic activities. This, in turn, stifled the economic initiative, hindering the capital adequacy and international competitiveness of Slovenian economic subjects.

7) Only companies able to develop a suitable scope of economy due to foreign (export) demand were able to adopt the capitalist operating principles. For this purpose they required capital and knowledge, which was provided by foreign entrepreneurs. Until as late as World War II the role of foreign capital and foreign entrepreneurs remained of key importance for the development of capitalist economy.

8) The fundamental dilemma of the Slovenian space and economic development reveals itself in the field of technological progress or more sophisticated business-operational structures. The relatively early or simultaneous modernisation beginnings of the transition to the new production technologies and business process organisations (or »islands of modernisation", as Sidney Pollard defines them) were not followed by a mass process. For a long time the first efforts remained isolated attempts, foreign elements in what was traditionally a dominantly agrarian economic environment at the level of technology as well as economic 
and social institutions. These first modernist phenomena remained exotic for so long that in the meantime their stimulating power to encourage structural changes and new institutional forms of economic life was completely exhausted.

\section{Literature}

- $\quad$ Allen, Robert (2001): "The Great Divergence in European Wages and Prices from Middle Ages to the First World War". In: Explorations in Economic History, 38, No. 4, pp. 411-447.

- Beaudoin, Steven M. (2000): "Current Debates in the Study of the Industrial Revolution". In: OAH Magazine of History, 15, No. 1, pp. 7-13.

- Berend, Ivan (2005), History Derailed. Central and Eastern Europe in the Long Nineteenth Century. Berkeley - Los Angeles: University of California Press.

- $\quad$ Braudel, Fernand (2010): Dinamika kapitalizma. Ljubljana: Sophia.

- Brenner Robert (1976): "Agrarian Class Structure and Economic Development in Pre-Industrial Europe". In: Past \& Present, 70, pp. 30-75.

- Brenner Robert (1989): "Economic Backwardness in Eastern Europe in Light of the Developments in the West". In: Chirot, Daniel (ed.), The Origins of Backwardness in Eastern Europe, pp. 15-52.

- Brezigar, Milko (1918): Osnutek slovenskega narodnega gospodarstva. Celje: Omladina/Zvezna tiskarna.

- Broadberry, Stephan (ed.), O’Rourke, Kevin H. (ed.) (2010): The Cambridge Economic history of Modern Europe. 1. 1700-1870. Cambridge: Cambridge University Press.

- Chirot, Daniel, (1989): Causes and Consequences of Backwardness. In: Chirot, Daniel (ed.), The Origins of Backwardness in Eastern Europe. University of California Press, pp. 1-13.

- Chirot, Daniel (ed.) (1989): The Origins of Backwardness in Eastern Europe. University of California Press

- Clark, Gregory (1987): "Productivity Growth without Technical Change in European Agriculture before 1850". In: The Journal of Economic History, 47, No. 2, pp. 419-432.

- Clark, Gregory (1983): "Productivity Growth Without Technical Change in European Agriculture. Reply to Komlos". In: The Journal of Economic History, 49, No. 4, pp. 979-991.

- Colleman, Donald C. (1983): "A Proto-Industrialization. A Concept Too Many". In: The Economic History Review, New Series, 36, No. 3, pp. 435-448.

- Damsgaard, Hansen (2001): European Economic History. From Mercantilism to Maastricht and Beyond. Copenhagen: Copenhagen Business School Press. 
- Di Vittorio, Antonio (2006): An Economic History of Europe. From Expansion to Development. London - New York: Routledge.

- Felloni, Giuseppe (1997): Profilo di storia economica dell'Europa. Dal medioevo all' eta contemporanea. Giappichelli: Turin.

- $\quad$ Fischer, Jasna, Vodopivec, Peter (1984), "O avtorju in njegovem delu". In: ŠORN, Jože, Začetki industrije na Slovenskem. Maribor: Založba Obzorja, pp. 5-8.

- Fischer, Jasna (2005): Družba, gospodarstvo, prebivalstvo. Družbena in poklicna struktura prebivalstva na slovenskem ozemlju od druge polovice 19. stoletja do razpada Habsburške monarhije. Ljubljana: INZ.

- Galbraith, John K. (1980), The Nature of Mass Poverty. London: The Penguin Books.

- Gerschenkron, Alexander (1979): Economic Backwardness in Historical Perspective. Belknap Press of Harvard University Press, pp. 5-30.

- Gestrin, Ferdo (1969): "Oris gospodarstva na Slovenskem v obodobju zgodnjega kapitalizma". In: Kronika, 17, No. 1, pp. 1-7.

- Gestrin, Ferdo (1969): "Oris gospodarstva na Slovenskem v obdobju agrarne revolucije in prevlade manufakturne proizvodnje". In: Kronika, 17, No. 2, pp. 65-71.

- Gestrin, Ferdo (1969): "Oris gospodarstva na Slovenskem v prvem obdobju kapitalizma". In: Kronika, 17, No. 3, pp. 129-137.

- Gestrin, Ferdo (1991): Slovenske dežele in zgodnji kapitalizem. Ljubljana: Slovenska matica.

- Gliha, Slavko (ed.), Kmetič, Ivanka (ed.), Koruza, Boris (ed.), Marinček, Lili (ed.) (1998): Zbornik ob 100-letnici Kmetijskega inštituta Slovenije. Ljubljana: Kmetijski inštitut Slovenije.

- Goldin, Claudia, Katz, Lawrence F. (2008), The Race between the Education and Techonology. Harvard University Press.

- Gunst, Peter (1989): Agrarian System of Central and Eastern Europe. In: Chirot (ed.), The Origins of Backwardness in Eastern Europe, pp. 53-91.

- Gustafsson, Bo (1996): "The Industrial revolution in Sweden". In: Teich, Mikulaš, Porter, Roy, The Industrial Revolution in National Context. Cambridge: Cambridge University Press, pp. 201-225.

- Higgins, Benjamin (1956): The "Dualistic Theory" of Underdeveloped Areas. In: Economic Development and Cultural Change, 4, No. 2, pp. 99-115.

- Hoffmann, Philip, Jacks, David, Levin, Patricia, Lindert, Peter (2002): Real Inequality in Europe since 1500. In: The Journal of Economic History, 62, No. 2, pp. 322-355.

- Komlos, John (1988): "Agricultural productivity in America and Eastern Europe. A Comment". In: The Journal of Economic History, 48, No. 3, pp. 655-664. 
- Krek, Janez Evangelist (1895): Črne bukve kmečkega stanu. Jedro kmečkega vprašanja. Ljubljana.

- Kresal, France (1969): "Vloga in pomen tekstilne industrije v industrializaciji 19. stoletja na Slovenskem". In: Kronika 17, No. 2, pp. 85-91.

- Lazarević, Žarko (1996): Friedrich List. Spurensuche in Slowenien. In: Wendler, Eugen (ed.). "Die Vereinigung des europäischen Kontinents". Friedrich List - Gesamteuropäische Wirkungsgeschichte seines ökonomischen Denkens. Stuttgart: Schäffer-Poeschel, pp. 529-539.

- Lazarević, Žarko (1998): "Slovensko kmetijstvo od zemljiške odveze do druge svetovne vojne". In: Gliha, Slavko (ed.), Kmetič, Ivanka (ed.), Koruza, Boris (ed.), MArinček, Lili (ed.), Zbornik ob 100-letnici Kmetijskega inštituta Slovenije. Ljubljana: Kmetijski inštitut Slovenije, pp. 13-30.

- Lazarević, Žarko (2007): "Sočasnosti slovenskega gospodarskega razvoja". In: Zgodovinski časopis, 61, No. 3-4, pp. 393-410.

- $\quad$ Lazarević, Žarko (2009): Plasti prostora in časa. Ljubljana: INZ, 2009.

- $\quad$ Lazarević, Žarko (2012): "Identitete in imena gospodarskega zgodovinopisja v Sloveniji". In: Ekonomska i ekohistorija, VIII/8, pp. 116-136.

- Lazarević, Žarko (2013): "Družba in gospodarstvo med obema vojnama. (Vprašanja ravni modernizacij)". In: Zgodovinski časopis, 67, No. 1-2, 110-134.

- Lorenčič, Aleksander (2012), Prelom starim in začetek novega. Tranzicija slovenskega gospodarstva iz socializma v kapitalizem. (1990-2004). Ljubljana: INZ.

- Massa, Paola (2006): "The Economy in Fifteen Century - Preconditions for European Expansion". In: Di Vittorio, Antonio, An Economic History of Europe. From Expansion to Development. London - New York: Routledge, pp. 1-25.

- Mendels, Franklin F. (1972): "Proto-Industrialization. The First Phase of the Industrialization Process". In: The Journal of Economic History, 32, 1972, No. 1, pp. 241-261.

- Mohorič, Ivan (1969): Dva tisoč let železarstva na Gorenjskem. Ljubljana: Mladinska knjiga, 1969.

- Mohorič, Ivan (1978): Problemi in dosežki rudarjenja na Slovenskem. Ljubljana: Založba Obzorja.

- Mohorič, Ivan (1968): Zgodovina železnic na Slovenskem. Ljubljana: Slovenska matica.

- More, Charles (2000), Understanding the industrial Revolution. London: Routlege, pp. 19-23.

- North, Douglas C.(1998), Inštitucije, inštitucionalne spremembe in gospodarska uspešnost. Ljubljana: Krtina.

- North, Douglas C. (2005): Understanding the process of economic change. Princeton: Princeton University Press. 
- Novak, Mojca (1991): Zamudniški vzorci industrializacije. Slovenija na robu Evrope. Ljubljana: znanstveno in publicistično središče.

- Ogilvie, Sheilagh C., Cerman, Mark (ed.) (2007): European Proto-Industrialization. Cambridge: Cambridge University Press.

- Ogilvie, Sheilagh C. (1995): "Institutions and Economic Development in Early Modern Central Europe". In: Transactions of the Royal Historical Society, Sixth Series, 5, pp. 221-250.

- Pančur, Andrej (2002): "Ekonomska vloga Avstro-Ogrske v evropskem prostoru s stališča modernizacijskih procesov in položaj posameznih dežel v njej". In: Prispevki za novejšso zgodovino, 42, No. 2, pp. 17-31.

- Pollard, Sidney (1973): "Industrialization and the European Economy". In: The Economic History Review, New Series, 26, No. 4, pp. 636-648.

- Pollard, Sidney (1996): "The industrial revolution - an overview". In: TEICH, Mikulaš, Porter, Roy, The Industrial Revolution in National Context. Cambridge: Cambridge University Press, pp. 371-387.

- Pollard, Sidney (2002): Peaceful Conquest. The Industrialization of Europe. 1760-1970. Oxford: Oxford University Press.

- Rakita, Milan (2011): "Prilog kritici teorija modernizacije i tranzitologije u društvenim naukama". In: Veselinović, Ana, Atanacković, Petar, Klarić, Željko, Izgubljeno u tranziciji. Kritička analiza procesa društvene transformacije. Beograd: Rosa Luxemburg Stiftung, pp. 7-32.

- $\quad$ Rostow, W. W. (1959): "The Stages of Economic Growth". In: The Economic History Review, New Series, 12, 1959, No. 1, pp. 1-16.

- Samuelson, Paul, Nordhaus, Paul -William (2002): Ekonomija. Ljubljana: GV Založba.

- Slovenska novejša zgodovina (2005): Inštitut za novejšo zgodovino, Mladinska knjiga, Ljubljana.

- Sočan, Lojze (1978): Pot v gospodarsko razvitost. Ljubljana: Delavska enotnost.

- Supan, Valentin C. (1869): Schutz der heimischen Arbeit. Laibach.

- Supan, Valentin C. (1876). Reflexionen ueber die oesterreichische Handelspolitik und Ideen, wie es bald besser werden kann. Laibach.

- Supan, Valentin C. (1876), "Politična ekonomija in politika". In: Slovenski narod, 49, 1 March 1876.

- Supan, Valentin C. (1877), Oesterreichs Volkswirtschaft - Handelspolitische Schriften mit Bezug auf die Zollverhandlungen mit Deutschland und Wendung der Handelspolitik am ganzen Kontinent England gegenueber. Laibach.

- Šorn, Jože (1984): Začetki industrije na Slovenskem. Maribor. Založba Obzorja.

- Teich, Mikulaš, Porter, Roy (1996): The Industrial Revolution in National Context. Cambridge: Cambridge University Press. 
- Tomić, Đorđe (2011): "Od transformacije do tranzicije i nazad. Nauka o transformaciji? Pojmovi, pitanja, teorije". In: Veselinović, Ana, Atanacković, Petar, Klarić, Željko, Izgubljeno u tranziciji. Kritička analiza procesa društvene transformacije. Beograd: Rosa Luxemburg Stiftung, pp. 33-56.

- Turnnock, David (2011): The Economy of East Central Europe. London: Reutledge, 2006.

- Veselinović, Ana, Atanacković, Petar, Klarić, Željko (2011): Izgubljeno u tranziciji. Kritička analiza procesa društvene transformacije. Beograd: Rosa Luxemburg Stiftung, pp. 7-58.

- Walton, John (1987): "Theory and Research on Industrialization". In: Annual Review of Sociology, 13, pp. 89-108.

- Wendler, Eugen (ed.) (1996). "Die Vereinigung des europäischen Kontinents". Friedrich List - Gesamteuropäische Wirkungsgeschichte seines ökonomischen Denkens. Stuttgart: Schäffer-Poeschel. 


\section{EKONOMSKA TRANZICIJA KAO KONTINUITET (O TRANZICIJI OD FEUDALIZMA DO KAPITALIZMA U SLOVENIJI)}

\section{S a ž e t a k}

Cilj ovog rada je bio da se utvrde zajedničke karakteristike procesa tranzicije, od feudalizma do kapitalizma, u Sloveniji. U procesima tranzicije do kapitalističke privrede, Slovenija je stalno bila na evropskoj periferiji. Izvozna tražnja je bila pokretačka snaga strukturnih promena u regionalnim okvirima, dok slaba unutrašnja tražnja nije mogla da deluje kao zamajac privrednog razvoja. Slovenačka privreda i društvo ušli su u ove procese sa višedecenijskim zakašnjenjem kao i sa izvesnim diskontinuitetom u formi deagrarizacije i deindustrijalizacije, kako je to objašnjeno konceptom proto-industrijalizacije. Tokom perioda deagrarizacije, preovladavao je model raspodele postojećih resursa. On se manifestovao u obliku usitnjavanja svojinske strukture u poljoprivredi, što je bio najznačajniji faktor relativne zaostalosti slovenačke teritorije. Slovenački ekonomski subjekti bili su mali, siromašni kapitalom, sa zastarelom tehnologijom, pa zbog toga nekonkurentni na međuregionalnom tržištu. Zbog toga su glavni nosioci ekonomskih promena bili strani preduzetnici sa njihovim know-how, kapitalom, tehnologijom i pristupom međunarodnom tržištu. U vremenu pre Drugog svetskog rata, uloga stranih investicija bila je od krucijalnog značaja za proces transformacije u kapitalističku privredu. Najznačajnije istorijsko obeležje privrednog razvoja Slovenije je činjenica da su „ostrva modernizacije“, koja su više ili manje bila u skladu sa evropskim trendovima, ostala „ostrva“ $i$ to samo dotle dok njihova snaga da stimulišu strukturne promene i nove institucionalne oblike privređivanja nije potpuno nestajala u pretežno agrarnoj ekonomskoj i društvenoj sredini.

Ključne reči: ekonomska tranzicija, privredni razvoj, socijalna transformacija, Slovenija 